\title{
KESESUAIAN EKOWISATA MANGROVE DITINJAU DARI ASPEK BIOGEOFISIK KAWASAN PANTAI GONDA DI DESA LALIKO KECAMATAN CAMPALAGIAN KABUPATEN POLEWALI MANDAR
}

\section{Mangrove Ecotourism Adjusment Reviewed Based on Biogeophysiscs Aspecs of Gonda Beach In The Villages of Laliko District of Campalagian Regency of Polewali Mandar}

\author{
Muhammad Sadik ${ }^{1}$, Amir Hamzah Muhiddin ${ }^{1 *}$, Marzuki Ukkas ${ }^{1}$ \\ Diterima: 5 Juli 2017 Disetujui: 21 Agustus 2017
}

\begin{abstract}
Ecotourism is a nature-based tourism activity that includes aspects of education and interpretation of the natural environment and community culture with ecological sustainability management. This study aims to determine the bioecological aspects of mangrove ecosystem as an object of ecotourism and to know the geophysical aspects of Gonda Beach as a supporter of mangrove ecotourism suitability on Gonda Beach. This research was conducted in November 2016 in Laliko Village, Campalagian Sub-district, Polewali Mandar Regency, including mangrove bioecological data collection including thickness, density, species and biota associated with mangrove and coastal geophysical data collection covering wide coastal measurement, coastal slope, depth, tidal, current, wave and substrate of waters. Result of research show potential of mangrove ecosystem to become ecotourism area with good condition of mangrove vegetation. The mangrove species in the ecosystem of the gonda mangroves are Bruguiera gymnorrhiza, Rhizophora stylosa, Rhizophora apiculata, Ceriops tagal, Sonneratia alba, Avicennia alba, Avicennia marina, Xylocarpus granatum and Xylocarpus moluccensis, and diverse biota such as fish, reptiles, birds and crabs as a tourist attraction. Gonda mangrove ecosystem area is a very suitable area to become a mangrove ecotourism area.
\end{abstract}

Keywords: ecotourism, mangrove, conformity analysis, tourism object

\section{PENDAHULUAN}

Istilah wilayah pesisir yang digunakan di Indonesia adalah daerah pertemuan antara darat dan laut. Ke arah darat, wilayah pesisir meliputi bagian daratan baik kering maupun terendam air, yang masih dipengaruhi sifat-sifat laut seperti pasang surut, angin laut, dan perembesan air asin. Ke arah laut wilayah pesisir mencakup bagian laut yang masih dipengaruhi oleh proses-proses alami yang terjadi di darat seperti sedimentasi dan aliran air tawar, maupun yang disebabkan oleh kegiatan manusia di darat seperti penggundulan hutan dan pencemaran (Dahuri, 1996). Ekosistem wilayah tersebut memiliki arti strategi karena memiliki potensi kekayaan hayati baik dari segi biologi, ekonomi dan pariwisata. Menurut Undang-Undang Nomor 9 Tahun 1990 tentang Kepariwisataan Bab I pasal 3, pariwisata adalah berbagai macam kegiatan wisata yang didukung

\footnotetext{
1 Departemen Ilmu Kelautan, Universitas Hasanuddin

* Amir Hamzah Muhiddin

Email: amirhamzahm@mar-sci.unhas.ac.id
}

berbagai fasilitas serta layanan yang disediakan oleh pihak yang bersangkutan, seperti masyarakat, pengusaha, pemerintah dan lain-lain. Pariwisata kemudian dimanfaatkan secara global dan dimodifikasi dengan berbagai konsep, termasuk ekowisata. Ekowisata adalah kegiatan wisata yang berbasis pada alam dengan menyertakan aspek pendidikan dan interpretasi terhadap lingkungan alami dan budaya mayarakat dengan pengelolaan kelestarian ekologis (Tuwo, 2011).

Salah satu ekosistem yang memiliki potensi yang dapat dikembangkan sebagai kawasan ekowisata adalah ekosistem mangrove. Hutan mangrove sebagai sumber daya alam hayati mempunyai keragaman potensi yang memberikan manfaat bagi kehidupan manusia. Manfaat yang dirasakan berupa berbagai produk dan jasa. Pemanfaatan produk dan jasa tersebut telah memberikan tambahan pendapatan dan bahkan merupakan penghasilan utama dalam pemenuhan kebutuhan hidup masyarakat. Salah satu jasa yang diperoleh dari manfaat hutan mangrove adalah berupa jasa ekowisata (Kustanti dkk., 2005). Secara umum 
ekosistem mangrove adalah tipe ekosistem yang terdapat di daerah pantai yang dipengaruhi pasang surut air laut, daerah pantai dengan kondisi tanah berlumpur, berpasir atau lumpur berpasir. Struktur komunitas ekosistem mangrove banyak dipengaruhi oleh faktor alam seperti pasang surut, salinitas, kondisi tanah/substrat serta asupan bahan organik maupun anorganik (Indriyanto, 2006). Gonda adalah salah satu kawasan yang berpotensi untuk dikembangkan sebagai kawasan ekowisata. Kawasan Gonda terletak di Kecamatan Campalagian, Kabupaten Polewali Mandar. Di kawasan ini selain terdapat ekosistem mangrove juga ekosistem terumbu karang. Saat ini masyarakat dan pemerintah setempat mencoba melakukan pengelolaan dan pengembangan Kawasan Gonda sebagai kawasan ekowisata dan sekaligus kawasan konservasi. Berdasarkanhal tersebutmaka dilakukan penelitian untuk mengetahui tingkat kelayakan Kawasan Gonda sebagai kawasan ekowisata.

\section{METODE PENELITIAN}

Penelitian ini dilaksanakan pada bulan November 2016 bertempat di Dusun Gonda Desa Laliko Kec. Campalagian Kab. Polewali Mandar Prov. Sulawesi Barat.

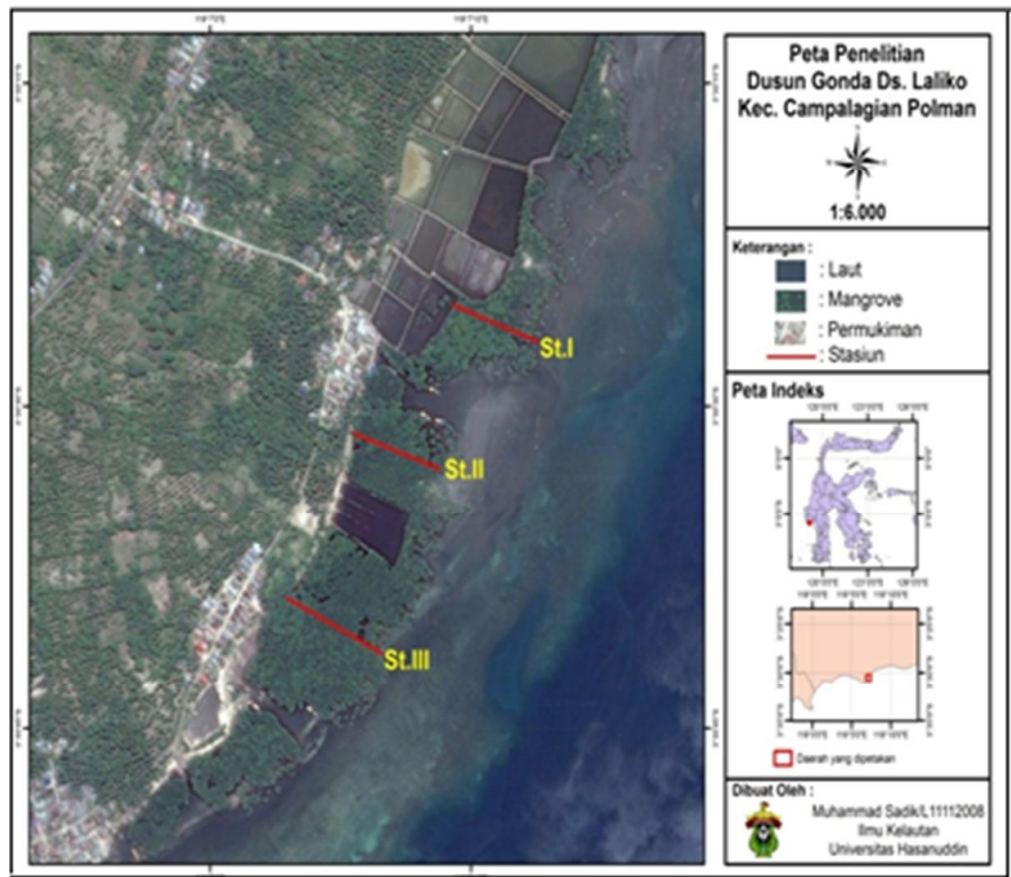

Gambar 1. Peta Lokasi Penelitian

Dalam penelitianinidilakukankan pemetaan topografi dan batimetri, analisis sedimen, pengukuran pasut, kecepatan arus, pengambilan contoh ikan dan udang dan pengamatan burung di areal mangrove, ketebalan dan kerapatan jenis mangrove. Pengukuran dan pengambilan sampling dilakukan di tiga stasiun pengukuran seperti terlihat pada Gambar 1.

Analisis kesesuaian wisata mangrove dilakukan berdasarkan matriks kesesuaian

Tabel 1. Matriks Kesesuaian Area Kategori Wisata Mangrove

\begin{tabular}{|c|c|c|c|c|c|c|c|c|c|}
\hline Parameter & Bobot & Kategori S1 & Skor & $\begin{array}{l}\text { Kategori } \\
\text { S2 }\end{array}$ & Skor & $\begin{array}{l}\text { Kategori } \\
\text { S3 } \\
\end{array}$ & Skor & $\begin{array}{c}\text { Kategori } \\
\mathbf{N} \\
\end{array}$ & Skor \\
\hline $\begin{array}{l}\text { Ketebalan } \\
\text { mangrove (m) }\end{array}$ & 0,35 & $>500$ & 4 & $>200-500$ & 3 & $50-200$ & 2 & $<50$ & 1 \\
\hline $\begin{array}{l}\text { Kerapatan } \\
\text { mangrove }\left(100 \mathrm{~m}^{2}\right)\end{array}$ & 0,25 & $>15-25$ & 4 & $>10-15$ & 3 & $5-10$ & 2 & $<5$ & 1 \\
\hline Jenis mangrove & 0,17 & $>5$ & 4 & $>3-5$ & 3 & $1-2$ & 2 & 0 & 1 \\
\hline Objek Biota & 0,13 & $\begin{array}{l}\text { ikan, udang, } \\
\text { kepiting, } \\
\text { moluska, reptil, } \\
\text { burung }\end{array}$ & 4 & $\begin{array}{c}\text { ikan, } \\
\text { udang, } \\
\text { kepiting, } \\
\text { moluska }\end{array}$ & 3 & $\begin{array}{c}\text { ikan, } \\
\text { moluska }\end{array}$ & 2 & $\begin{array}{c}\text { salah } \\
\text { satu } \\
\text { biota air }\end{array}$ & 1 \\
\hline Pasang surut (m) & 0,10 & $0-1$ & 4 & $>1-2$ & 3 & $>2-5$ & 2 & $>5$ & 1 \\
\hline
\end{tabular}

Sumber : Modifikasi Modul Sosialisasi dan Orientasi Penataan Ruang Laut, Pesisir dan Pulau-pulau Kecil (2002), Yulianda (2007), Bakosurtanal (1995) dan Purbani (1999)

Keterangan: $\quad$ Nilai maksimum $=4$

Kategori Kesesuaian (\%) S1 = Sangat sesuai, dengan nilai $75-100 \%$

Kategori Kesesuaian (\%) S2 = Sesuai, dengan nilai $50-75 \%$

Kategori Kesesuaian (\%) S3 = Sesuai bersyarat, dengan nilai $25-50 \%$

Kategori Kesesuaian (\%) N = Tidak sesuai, dengan nilai $25 \%$ 
Tabel 2. Matriks Kesesuaian Wisata Pantai

\begin{tabular}{lllclclc}
\hline Parameter & Bobot & Kategori S1 & Skor & Ketegori S2 & Skor & Kategori N & Skor \\
\hline Lebar Pantai & 0,250 & $>10$ & 3 & $3-<10$ & 2 & $<3$ & 1 \\
Kelandaian Pantai & 0,214 & datar/landai & 3 & curam & 2 & terjal & 1 \\
Kedalaman (m) & 0,179 & $0-3$ & 3 & $3-6$ & 2 & $>6$ & 1 \\
Substrat & 0,143 & berpasir & 3 & $\begin{array}{l}\text { berpasir sedikit } \\
\text { karang }\end{array}$ & 2 & berlumpur & 1 \\
Kecepatan Arus (m/detik) & 0,117 & $0-0,17$ & 3 & $0,017-0,51$ & 2 & $>0,51$ & 1 \\
Gelombang & 0,097 & $0-1$ & 3 & $1-2$ & 2 & $2-3$ & 1 \\
\hline
\end{tabular}

Sumber: Purbani (1997), Widiatmaka (2007) dan Yulianda (2007) dan hasil modifikasi (2012)

$\begin{array}{lll}\text { Keterangan: } & \text { Jumlah } & =\text { Skor } \times \text { Bobot } \\ & \text { Nilai Maksimum } & =3 \\ & \text { Kategori S1 } & =\text { Sesuai } \\ & \text { Ketegori S2 } & =\text { Cukup sesuai } \\ & \text { Kategori N } & =\text { Tidak sesuai }\end{array}$

(Tabel 1), analisis kesesuaian wisata pantai (Tabel 2), analisis kesesuaian lahan (Tabel 3).

Penentuan Indeks Kesesuaian Wisata dilakukan dengan menggunakan rumus sebagai berikut (Yulianda, 2007):

$$
\mathrm{IKW}=\sum\left(\frac{\mathrm{Ni}}{\text { Nmaks }}\right) \times 100 \%
$$

Keterangan:

$$
\begin{aligned}
\mathrm{IKW}= & \text { Indeks Kesesuaian Wisata } \\
\mathrm{Ni}= & \text { Nilai Parameter ke-I (Bobot } \mathrm{x} \\
& \text { Skor) } \\
\text { Nmaks }= & \text { Nilai maksimum dari suatu } \\
& \text { kategori wisata. }
\end{aligned}
$$

Tabel 3. Kesesuaian Lahan Berdasarkan Interval Kesesuaian

\begin{tabular}{lll}
\hline No & Ketegori & $\begin{array}{l}\text { Nilai interval } \\
\text { kesesuaian }\end{array}$ \\
\hline 1 & S1 (sesuai) & $77,78-100 \%$ \\
2 & S2 (Cukup sesusai) & $55,56-77,78 \%$ \\
3 & N (Tidak sesuai) & $<55,56 \%$ \\
\hline
\end{tabular}

\section{Ketebalan mangrove}

Ketebalan mangrove diukur berdasarkan panjang bentangan roll meter di setiap stasiun secara tegak lurus dari batas darat sampai batas laut.

\section{Kerapatan jenis}

Kerapatan Jenis (Di) adalah jumlah tegakan jenis $i$ dalam suatu unit area:

Keterangan:

$$
D i=\frac{n i}{\mathrm{~A}}
$$

$D i$ : Kerapatan jenis (ind $/ \mathrm{m}^{2}$ ) ni : Jumlah total tegakan jenis $i$

A : Luas total area pengambilan contoh $(\mathrm{m} 2)$

\section{Pasang Surut}

$$
M S L=\frac{\sum H i \times C i}{\left.\sum C i\right)}
$$

Keterangan:

MSL : Tinggi muka air rata-rata $(\mathrm{cm})$

$\mathrm{H}$ : Tinggi muka air $(\mathrm{cm})$

Ci : Konstanta Doodson

\section{Gelombang}

Tinggi Gelombang

$\mathrm{H}=$ (puncak gelombang-lembah gelombang)

Tinggi Gelombang Signifikan

$\mathrm{H} \frac{1}{3}=$ Rata-rata dari $\frac{1}{3}$ gelombang terbesar setelah diurutkan.

Keterangan:

$$
\begin{aligned}
& \mathrm{H} \text { : Tinggi Gelombang } \\
& \mathrm{n} \text { : Banyaknya Gelombang }
\end{aligned}
$$

Arus

Keterangan:

$$
V=\frac{s}{t}
$$

$$
\begin{aligned}
& \mathrm{V}: \text { Kecepatan Arus (m/detik) } \\
& \mathrm{s} \quad: \text { Jarak }(\mathrm{m}) \\
& \mathrm{t} \quad \text { : Waktu yang ditempuh }
\end{aligned}
$$

\section{Kedalaman}

$$
\mathrm{Ds}=\mathrm{Dt}+(\mathrm{MSL}-\mathrm{ht})
$$

Keterangan:

Ds : Kedalaman sebenarnya $(\mathrm{m})$

Dt : Kedalaman saat pengukuran (m)

MSL : Nilai muka air rata-rata

ht : Tinggi muka air saat pengukuran (m)

\section{Besar Butir Sedimen}

Untuk menghitung persen (\%) berat butir sedimen menggunakan rumus: 
$\%$ Berat $=\frac{\text { Berat hasil Ayakan }}{\text { Berat awal }} \times \mathbf{1 0 0} \%$

Untuk menghitung persen (\%) kumulatif

$\%$ Kumulatif $=\%$ berat $1+\%$ berat 2

Analisis substrat sedimen dilakukan berdasarkan Skala Wenworth (Hutabarat dan Evans, 1985):

Tabel 4. Analisis Substrat Sedimen, Menggunakan Skala Wenworth

\begin{tabular}{lc}
\hline Kelas Ukuran Butir & Diameter Butir (mm) \\
\hline Boulders (Kerikil Besar) & $>256$ \\
Gravel (Kerikil Kecil) & $2-256$ \\
$\begin{array}{l}\text { Very coarse sand (Pasir } \\
\text { Sangat Kasar) }\end{array}$ & $1-2$ \\
Coarse sand (Pasir Kasar) & $0,5-1$ \\
$\begin{array}{l}\text { Medium sand (Pasir } \\
\text { Sedang) }\end{array}$ & $0,25-0,5$ \\
Fine Sand (Pasir Halus) & $0,125-0,25$ \\
$\begin{array}{l}\text { Very fine sand (Pasir } \\
\text { Sangat Halus) }\end{array}$ & $0,0625-0,125$ \\
$\begin{array}{l}\text { Silt (Debu) } \\
\text { Clay (Lempung) }\end{array}$ & $0,002-0,0625$ \\
$\begin{array}{l}\text { Dissolved material } \\
\text { (Material Terlarut) }\end{array}$ & $0,0005-0,002$ \\
\hline
\end{tabular}

\section{HASIL DAN PEMBAHASAN}

\section{Gambaran Umum Lokasi Penelitian}

Kawasan Gonda secara administratif masuk dalam administrasi Dusun Gonda, Desa Laliko, Kecamatan Campalagian, Kabupaten Polewali Mandar, Provinsi Sulawesi Barat. Secara Geografis Desa Laliko terletak pada 330'18.63" LS dan $119^{\circ} 6^{\prime} 56.34^{\prime \prime}$ BT dengan batas wilayah yaitu Sebalah Utara Desa Suruang, Sebelah Timur Desa Lapeo, Sebelah Selatan Teluk Mandar, Sebelah Barat Desa Bala. Ekosistem mangrove sudah puluhan tahun tumbuh secara alami di sepanjang Dusun Gonda dan masyarakat setempat hanya menggunakan mangrove sebagai tempat sandar kapal, mencari kepiting, ikan dan udang serta kayu bakar.

Pengelolaan Kawasan Gonda sebagai kawasan objek wisata dilakukan masyarakat dengan merehabilitasi mangrove dan membangun kerja sama dengan berbagai organisasi pemuda dan pihak pemerintah. Tujuan utama kawasan ini dijadikan obyek wisata adalah agar masyarakat setempat bisa mendapatkan penghasilan tam- bahan selain dari pekerjaan sehari-hari. Baiquni (2010) menyatakan bahwa wisata berbasis eksostem ini dapat dimanfaatkan untuk mendorong perubahan hidup melalui peluang kerja yang tersedia, meningkatkan pendapatan, dan membaiknya kualitas hidup masyarakat.

Fasilitas penunjang yang telah disediakan seperti area tempat istirahat berupa tempat duduk, gazebo, rumah baca, warung, beberapa fasilitas lainnya seperti ayunan, perahu kecil dan perahu sedang serta area parkir dan sumur untuk membasuh badan setelah berenang. Fasilitas-fasilitas yang telah disediakan tidak hanya untuk para pengunjung yang datang tetapi juga untuk masyarakat setempat sebagai wujud pemberdayaan masyarakat setempat. Selain itu, untuk memperoleh penghasilan tambahan maka masyarakat setempat diberikan kesempatan untuk menyewakan perahu, menjual makanan dan minuman dan lain sebagainya.

\section{Ketebalan Mangrove}

Dari hasil pengukuran yang dilakukan secara tegak lurus terhadap garis pantai maka diperoleh ketebalan mangrove sebagai berikut:

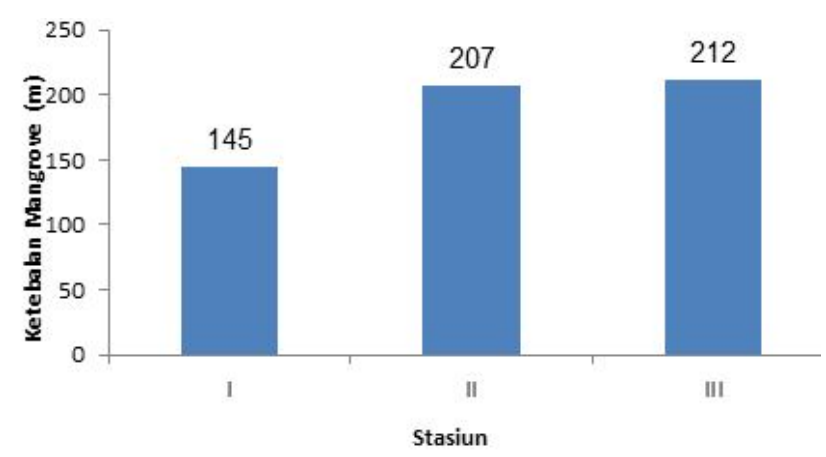

Gambar 2. Ketebalan Mangrove

Ketebalan ekosistem mangrove menunjukkan bahwa pertumnuhan mangrove di kawasan ini terjadi secara alami dan belum terganggu aktivitas masyarakat. Kondisi ini menunjang tetap terjaganya ekosistem mangrove dan sekaligus menunjang kegiatan ekowisata mangrove.

\section{Komposisi Jenis Mangrove}

Hasil idetifikasi menunjukkan bahwa terdapat 9 jenis mangrove yang di kawasan ini yaitu jenis Bruguiera gymnorrhiza, Rhizophora stylosa, Rhizophora apiculata, Ceriops tagal, Sonneratia alba, Avicennia alba, Avicennia marina, Xylocarpus granatum dan Xylocarpus moluccensis.

Beragamnya jenis mangrove di kawasan ini menjadi daya tarik bagi pengunjung untuk melakukan wisata dan kegiatan edukasi yang 
Tabel 5. Komposisi Jenis Mangrove

\begin{tabular}{lllll}
\hline \multirow{2}{*}{ No } & \multirow{2}{*}{ Spesies } & \multicolumn{3}{c}{ Stasiun } \\
\cline { 3 - 5 } & & I & II & III \\
\hline 1 & Brugueira gymnorrhiza & $\sqrt{ }$ & $\sqrt{ }$ & $\sqrt{ }$ \\
2 & Rhizophora stylosa & $\sqrt{ }$ & $\sqrt{ }$ & $\sqrt{ }$ \\
3 & Rhizophora apiculata & $\sqrt{ }$ & $\sqrt{ }$ & $\sqrt{ }$ \\
4 & Ceriops tagal & $\sqrt{ }$ & $\sqrt{ }$ & $\sqrt{ }$ \\
5 & Sonneratia alba & & $\sqrt{ }$ & \\
6 & Avicennia alba & & $\sqrt{ }$ & $\sqrt{ }$ \\
7 & Avicennia marina & & $\sqrt{ }$ & \\
8 & Xylocarpus granatum & $\sqrt{ }$ & & \\
9 & Xylocarpus moluccensis & \multicolumn{3}{c}{$\sqrt{ }$} \\
\hline
\end{tabular}

berhubungan dengan ekosistem mangrove. Banyaknya jenis mangrove juga menjadi suatu hal yang sangat menunjang untuk beragamnya biota yang berasosiasi serta menjadi habitat utama biota lainnya. Ekowisata mangrove dan edukasi mangrove bisa menjadi pilihan yang akan digemari oleh para wisatawan, karena dapat menikmati alam yang indah, udara yang sejuk serta dapat menambah wawasan tentang lingkungan hidup dan pentingnya ekosistem mangrove dalam struktural ekosistem pesisir.

\section{Kerapatan Mangrove}
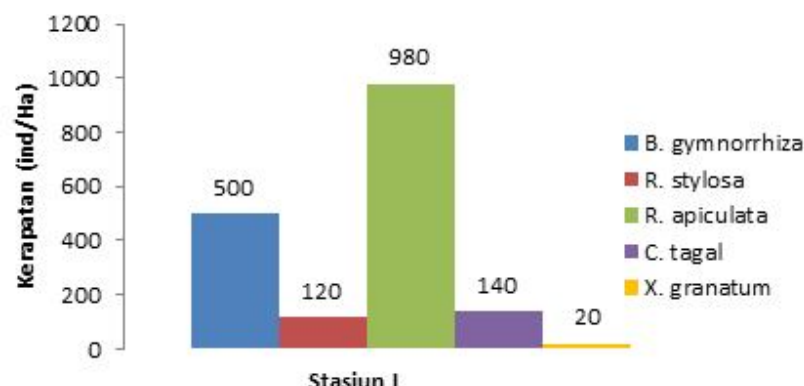

Gambar 3. Kerapatan Mangrove Stasiun I

Kerapatan total seluruh plot stasiun I adalah 1760 ind/Ha, berdasarkan kriteria baku mutu kerusakan mangrove, Kepmeneg LH No. 201 Tahun 2004, maka kerapatan mangrove pada stasiun ini dapat diklasifikasikan sebagai mangrove yang padat.

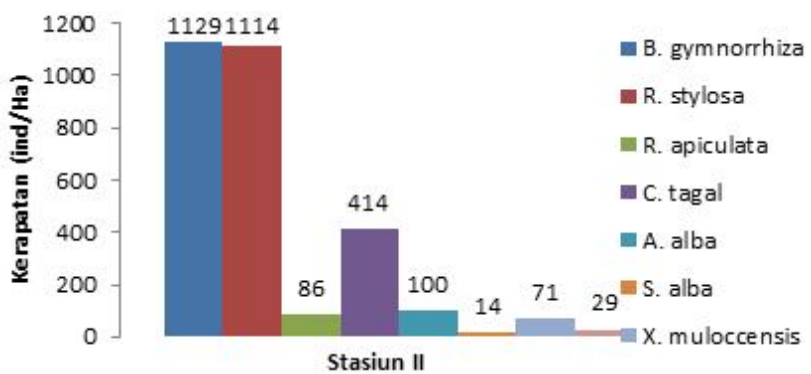

Gambar 4. Kerapatan Mangrove Stasiun II
Kerapatan total seluruh plot stasiun II adalah 2957 ind/Ha, berdasarkan kriteria baku mutu kerusakan mangrove, Kepmeneg LH No. 201 Tahun 2004, maka kerapatan mangrove pada stasiun ini termasuk mangrove yang sangat padat.

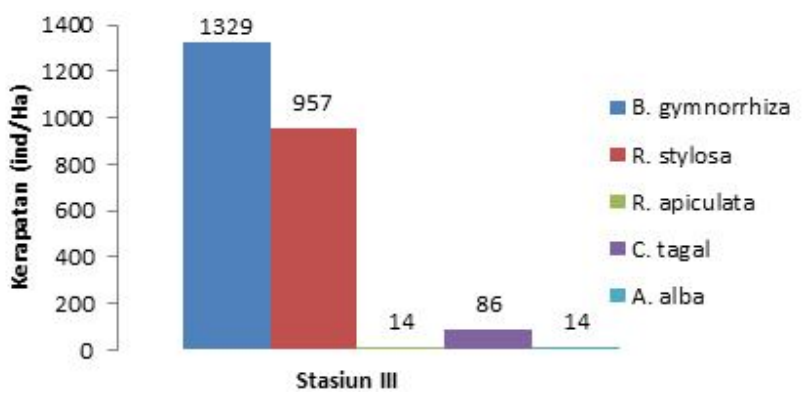

Gambar 5. Kerapatan Mangrove Stasiun III

Kerapatan total seluruh plot stasiun III adalah 2400 ind/Ha, berdasarkan kriteria baku mutu kerusakan mangrove, Kepmeneg LH No. 201 Tahun 2004, maka kerapatan mangrove pada stasiun ini termasuk mangrove yang sangat padat.

\section{Biota Berasosiasi}

Objek biota ekosistem mangrove yang dapat dinikmati secara langsung selain memberikan kepuasan tersendiri bagi para pengunjung yang datang juga memberikan nilai lebih suatu kawasan ekowisata mangrove. Dari pengamatan yang dilakukan didapatkan hasil sebagai berikut:

Ikan

Tabel 6. Jenis Ikan

\begin{tabular}{llll}
\hline No & Nama Latin & $\begin{array}{l}\text { Nama } \\
\text { Indonesia }\end{array}$ & $\begin{array}{l}\text { Nama } \\
\text { Daerah }\end{array}$ \\
\hline 1 & Periopthalmus sp. & Gelodok & Kondong \\
2 & Chanos-chanos & Bandeng & Bolu \\
3 & Mugilidae & Balanak & Balana' \\
\hline
\end{tabular}

\section{Reptil}

Tabel 7. Jenis Reptil

\begin{tabular}{llll}
\hline No & Nama Latin & $\begin{array}{l}\text { Nama } \\
\text { Indonesia }\end{array}$ & $\begin{array}{l}\text { Nama } \\
\text { Daerah }\end{array}$ \\
\hline 1 & Varanus $s p$. & Biawak & Puarang \\
2 & Dasia $s p$. & Kadal & Kadal \\
\hline
\end{tabular}




\section{Burung}

Tabel 8. Jenis Burung

\begin{tabular}{llll}
\hline No & Nama Latin & Nama Indonesia & Nama Daerah \\
\hline 1 & Egretta garzetta & Kuntul Kecil & Dakko \\
2 & Zosterops chioris & Kacamata Laut & Dassi-dassi \\
3 & Actitis hypolecos & Trinil Pantai & Cecakkeo \\
4 & Locustella fasciolata & Kecici gray & Cammi-cammi \\
\hline
\end{tabular}

\section{Kepiting}

Tabel 9. Jenis Kepiting

\begin{tabular}{llll}
\hline No & Nama Latin & Nama Indonesia & Nama Daerah \\
\hline 1 & Scylla serrata & $\begin{array}{l}\text { Kepiting Bakau / } \\
\text { Kepiting Hijau }\end{array}$ & Buang Sudir \\
2 & Thalamita sp. & Kepiting Bakau & Buang Bakko \\
\hline
\end{tabular}

\section{Pasang Surut}

Berdasarkan hasil penelitian dan pengukuran yang dilakukan di kawasan mangrove gonda maka diperoleh hasil pasang surut sebagai berikut.

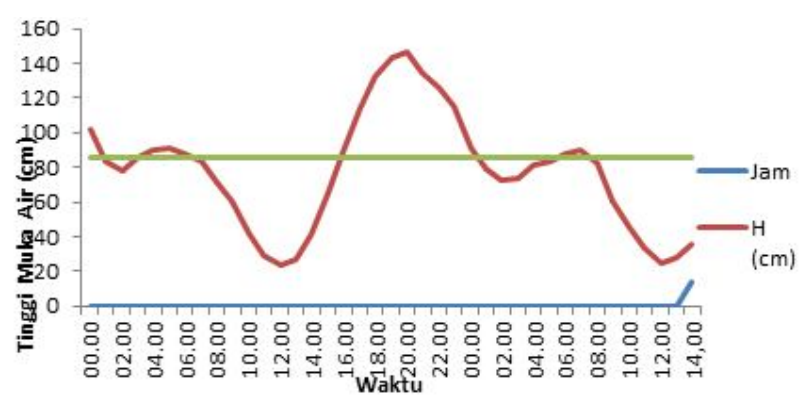

Gambar 6. Grafik Pasang Surut

Tipe pasang surut pada perairan pantai gonda adalah pasang surut campuran condong harian ganda (Mixed Tide, Prevailing Semi Diurnal). Terjadi dua kali pasang dan dua kali surut dalam sehari tetapi terkadang terjadi satu kali pasang dan satu kali surut dengan memiliki tinggi dan waktu yang berbeda.

\section{Lebar Pantai}

Dari pengukuran yang dilakukan pada stasiun I dan sekitarnya didapatkan bahwa lebar pantai pada saat surut terendah yaitu $30 \mathrm{~m}$ diukur dari garis pantai ke mangrove dan $250 \mathrm{~m}$ diukur dari garis pantai sampai kedalaman 1,50 $\mathrm{m}$ yang diasumsikan sebagai batas aman untuk melakukan kegiatan.

\section{Kelandaian}

Topografi pantai dihasilkan dari pengukuran beda tinggi menggunakan waterpass, tiang skala dan GPS. Dari hasil pengukuran ini dihasilkan peta topografi Kawasan Gonda selanjutnya kelandaian pantai ditentukan di atas peta topografi.

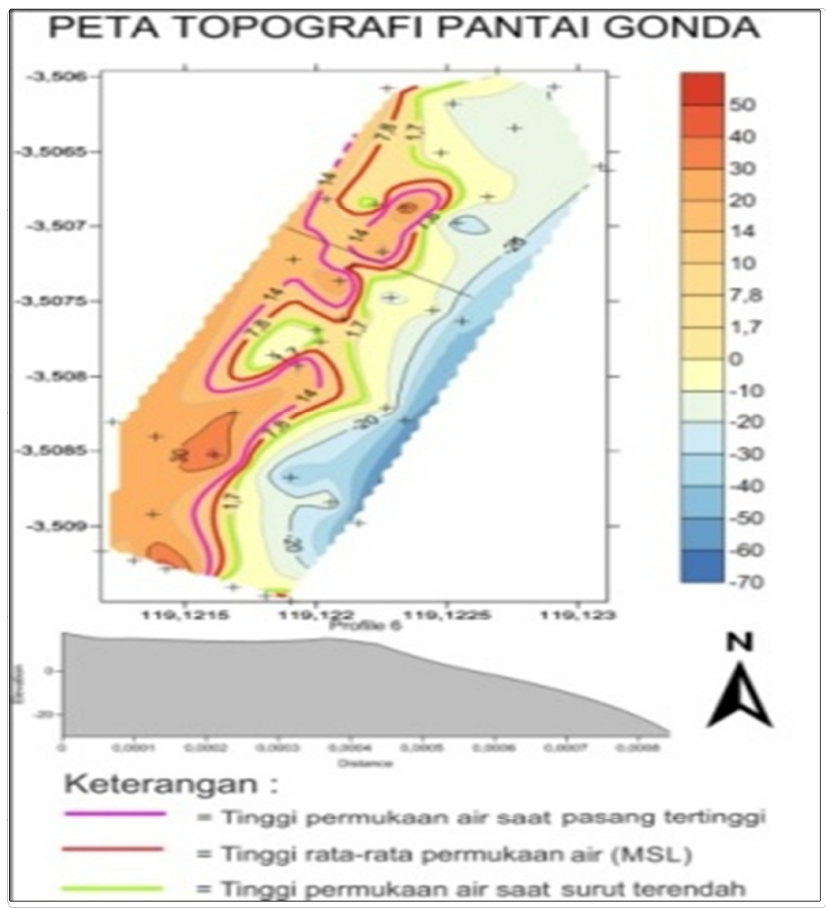

Gambar 7. Peta Topografi Pantai Gonda

Peta topografi Pantai Gonda menunjukan bahwa topografi pada tempat penelitian merupakan daerah dataran rendah dengan ketinggian $0-0,5 \mathrm{~m}$ diatas permukaan laut. Garis pantai pada saat pasang tertinggi adalah $58 \mathrm{~cm}$ dari MSL sedangkan garis pantai pada saat surut terendah adalah $-72 \mathrm{~cm}$ dari MSL. Berdasarkan peta topografi di atas maka pantai Kawasan Gonda dapat diklasifikasikan sebagai pantai yang datar.

\section{Kedalaman}

Kedalaman merupakan aspek yang penting untuk diketahui pada suatu kawasan wisata pantai karena aspek ini sangat berpengaruh terhadap keselamatan para pengunjung yang melakukan kegiatan mandi dan berenang. Terkait dengan kedalaman, Widiatmaka (2007) dalam Armos (2013) memberikan batasan nilai kedalaman bagi kesesuaian perairan untuk wisata pantai dengan kategori cukup sesuai yaitu antara 3-6 m. 
Tabel 10. Kedalaman Perairan

\begin{tabular}{cccl}
\hline $\begin{array}{c}\text { Kedalaman } \\
\text { Terukur (Dt) }\end{array}$ & $\begin{array}{c}\text { Kedalaman } \\
\text { Sebenarnya (DS) }\end{array}$ & $\begin{array}{c}\text { Jarak dari } \\
\text { Pantai }\end{array}$ & Keterangan \\
\hline $1,50 \mathrm{~m}$ & $2,10 \mathrm{~m}$ & $250 \mathrm{~m}$ & Pada saat surut \\
$1,50 \mathrm{~m}$ & $1,21 \mathrm{~m}$ & $100 \mathrm{~m}$ & Pada saat pasang \\
\hline
\end{tabular}

\section{Substrat}

Kondisi subtrat pada suatu kawasan wisata juga menjadi salah satu daya tarik bagi para pengunjung. Berdasarkan dari hasil pengamatan yang dilakukan, diperoleh substrat ukuran 0,125 dengan berat sedimen (\%) pada ulangan 1 sebesar 61,8536, ulangan 2 sebesar 68,2935, ulangan 3 sebesar 70,1099 mm termasuk dalam ketegori pasir halus (Gambar 8), hal ini sesuai dengan pendapat Widiatmaka (2007) dalam Armos (2013) yang menyatakan bahwa pariwisata pantai akan sangat baik jika pantainya berpasir atau dengan kata lain didominasi oleh substrat pasir, dibandingkan dengan pantai yang berbatu atau pantai yang didominasi oleh substrat karang karena substrat yang kasar seperti karang dapat menggangu kenyamanan wisatawan.
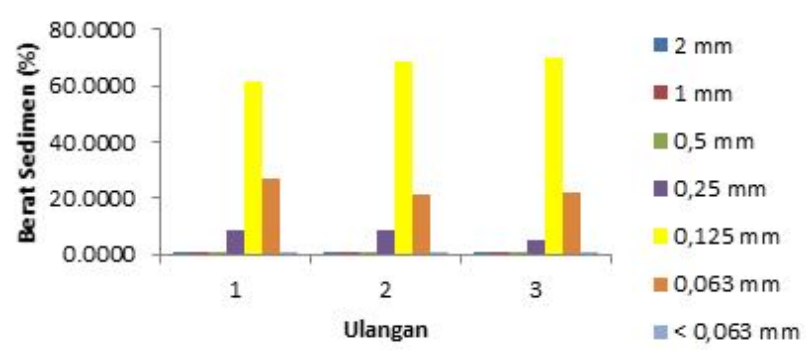

Gambar 8. Ukuran Besar Butir Sedimen

\section{Arus}

Berdasarkan arus yang diukur selama 10 jam dengan interval 1 jam mulai dari jam 08:00 WITA sampai jam 18:00 WITA, menunjukkan bahwa arus pada perairan ini cenderung lemah. Data arus disajikan pada gambar 9.

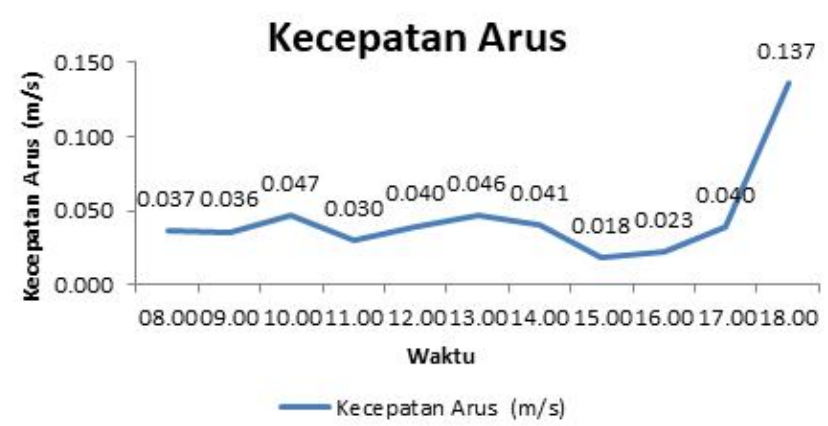

Gambar 9. Kecepatan Arus Sesaat
Nontji (2002) menyatakan bahwa arus yang lemah sangat baik untuk kegiatan renang sedangkan arus yang kuat sangat berbahaya karena dapat menyeret orang yang sedang mandi atau berenang di pantai.

\section{Gelombang}

Berdasarkan data gelombang yang diukur selama 10 jam dengan interval 1 jam mulai dari jam 08:00 WITA sampai jam 18:00 WITA, menunjukkan bahwa gelombang pada perairan ini relatif kecil. Gelombang dapat menjadi salah satu faktor yang perlu diperhatikan untuk melihat tingkat keamanan para wisatawan yang melakukan kegiatan renang. Data gelombang signifikan disajikan pada Gambar 10.

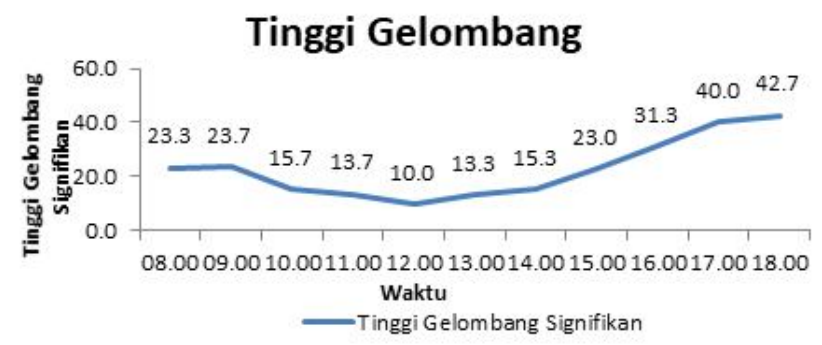

Gambar 10. Tinggi gelombang

\section{Analisis Kesesuaian Kawasan Ekowisata Mangrove}

Bedasarkan hasil penelitian yang dilakukan maka dapat diketahui tingkat kesesuaian kawasan mangrove seperti tampak pada Tabel 11. 
SPERMONDE (2017) 2(3): 25-33

Tabel 11. Matriks Kesesuaian Ekowisata Mangrove Pantai Gonda

\begin{tabular}{|c|c|c|c|c|c|c|c|c|c|c|c|}
\hline \multirow[b]{2}{*}{ No } & \multirow[b]{2}{*}{ Paramater } & \multirow[b]{2}{*}{ Bobot } & \multicolumn{3}{|c|}{ Stasiun I } & \multicolumn{3}{|c|}{ Stasiun II } & \multicolumn{3}{|c|}{ Stasiun III } \\
\hline & & & Hasil & Skor & $\begin{array}{l}\text { Bobot } \\
\text { x Skor } \\
\end{array}$ & Hasil & Skor & $\begin{array}{c}\text { Bobot } \\
\text { x Skor } \\
\end{array}$ & Hasil & Skor & $\begin{array}{l}\text { Bobot } \\
\text { x Skor }\end{array}$ \\
\hline 1 & $\begin{array}{l}\text { Ketebalan/Lebar } \\
\text { manggrove(m) }\end{array}$ & 0,35 & 145 & 2 & 0,7 & 207 & 3 & 1,05 & 212 & 3 & 1,05 \\
\hline 2 & $\begin{array}{l}\text { Kerapatan } \\
\text { manggrove } \\
\text { (ind/100m2) }\end{array}$ & 0,25 & 18 & 4 & 1 & 30 & 4 & 1 & 24 & 4 & 1 \\
\hline 3 & Jenis manggrove & 0,17 & 5 & 3 & 0,51 & 8 & 4 & 0,68 & 5 & 3 & 0,51 \\
\hline 4 & Objek Biota & 0,13 & $\begin{array}{l}\text { ikan, } \\
\text { kepiting, } \\
\text { reptil, } \\
\text { burung }\end{array}$ & 3 & 0,39 & $\begin{array}{l}\text { kepiting, } \\
\text { reptil, } \\
\text { burung }\end{array}$ & 2 & 0,26 & $\begin{array}{l}\text { reptil, } \\
\text { burung }\end{array}$ & 2 & 0,26 \\
\hline 5 & Pasang Surut (m) & 0,1 & 0,85 & 4 & 0,4 & 0,85 & 4 & 0,4 & 0,85 & 4 & 0,4 \\
\hline & & Total & & & 3 & & & 3,39 & & & 3,22 \\
\hline
\end{tabular}

Berdasarkan kategori kesesuaian kawasan setiap stasiun maka dilakukan penilaian kesesuaian kawasan ekowisata mangrove sebagai berikut:

Tabel 12. Hasil Penilaian Kesesuaian Kawasan Ekowisata Mangrove Pantai Gonda

\begin{tabular}{lccccccc}
\hline \multirow{2}{*}{ Parameter } & Bobot & \multicolumn{6}{c}{ Stasiun } \\
\cline { 3 - 8 } & & \multicolumn{5}{c}{ I } & \multicolumn{2}{c}{ II } & \multicolumn{2}{c}{ III } \\
\cline { 3 - 8 } & & Skor & Nilai & Skor & Nilai & Skor & Nilai \\
\hline $\begin{array}{l}\text { Ketebalan/Lebar } \\
\text { mangrove (m) }\end{array}$ & 0,35 & 2 & 0,7 & 3 & 1,05 & 3 & 1,05 \\
$\begin{array}{l}\text { Kerapatan mangrove } \\
\text { (ind/100m2) }\end{array}$ & 0,25 & 4 & 1 & 4 & 1 & 4 & 1 \\
Jenis Mangrove & 0,17 & 3 & 0,51 & 4 & 0,68 & 3 & 0,51 \\
Objek Biota & 0,13 & 3 & 0,52 & 2 & 0,52 & 2 & 0,52 \\
Pasang Surut (m) & 0,10 & 4 & 0,3 & 4 & 0,2 & 4 & 0,2 \\
\hline Jumlah Total & & & 3,00 & & 3,39 & & 3,22 \\
Nilai Kesesuaian & & & $75 \%$ & & $84 \%$ & & $80 \%$ \\
Kategori Kesesuaian & & & S2 & & S1 & & S1 \\
\hline
\end{tabular}

Berdasarkan tebel diatas dapat disimpulkan bahwa indeks kesesuaian wisata kawasan mangrove pada stasiun I adalah $75 \%$ dengan kategori sesuai, stasiun II adalah $84 \%$ dengan kategori sangat sesuai, dan stasiun III adalah $80 \%$ dengan kategori sangat sesuai.

\section{Analisis Kesesuaian Kawasan Wisata Pantai}

Adapun analisis kesesuaian kawasan wisata pantai adalah sebagai berikut :
Tabel 13. Tingkat Kesesuaian Kawasan Pantai Gonda

\begin{tabular}{lcccc}
\hline \multicolumn{1}{c}{ Parameter } & Bobot & $\begin{array}{c}\text { Hasil } \\
\text { Penelitian }\end{array}$ & Skor & $\begin{array}{c}\text { Bobot } \mathbf{x} \\
\text { Skor }\end{array}$ \\
\hline Lebar Pantai & 0,250 & 30 & 3 & 0,750 \\
Kelandaian & 0,214 & $\begin{array}{c}\text { Datar/ } \\
\text { Lantai }\end{array}$ & 3 & 0,642 \\
Kedalaman (m) & 0,179 & 2,1 & 3 & 0,537 \\
Substrat & 0,143 & Berpasir & 3 & 0,429 \\
Kec. Arus (m/s) & 0,117 & 0,045 & 2 & 0,234 \\
Gelombang (cm) & 0,097 & 22,9 & 3 & 0,291 \\
\hline Total & & & & 2,883 \\
Nilai Kesesuaian & & & & $96 \%$ \\
Kategori Kesesuaian & & & $\mathrm{S} 1$ \\
\hline
\end{tabular}

Tabel di atas menunjukkan bahwa kawasan Pantai Gonda dapat diklasifikasikan kedalam kategori pantai yang sesuai untuk kawasan wisata dengan nilai indeks kesesuaian adalah $96 \%$.

\section{KESIMPULAN}

Dari hasil analisis kesesuaian kawasan ekosistem mangrove Pantai Gonda dapat disimpulkan bahwa pantai wisata Gonda adalah pantai wisata yang dikategorikan kedalam kategori sangat sesuai untuk menjadi kawasan ekowisata mangrove. Hasil analisis kesesuaian wisata Pantai Gonda termasuk ketegori sesuai sehingga sangat mendunkung kawasan ekowisata mangrove pada Pantai Gonda untuk menambah daya tarik pengunjung 


\section{DAFTAR PUSTAKA}

Armos, N.H. 2013. Studi Kesesuaian Lahan Pantai Wisata Boe Desa Mappakalompo Kecamatan Galesong Ditinjau Berdasarkan Biogeofisik. Skripsi. Fakultas Ilmu Kelautan dan Perikanan Universitas Hasanuddin. Makassar

Baiquni, M. 2010. Pariwisata Berkelanjutan dalam Pusaran Krisis Global, Pariwisata dan Krisis Lingkungan Global. Udayana University Press. Denpasar, Bali.

Dahuri, R., J., Rais, SP, Ginting, M, J. Sitepu. 1996. Pengelolaan Sumber Daya Pesisir Wilayah Pesisisr dan Lautan Secara Terpadu., PT. Pradyna Paramita, Jakarta.

Widiatmaka, Hardjowigeno, Sarwono. 2007. Evaluasi Kesesuaian Lahan $\mathcal{E}$ PerencanaanTataguna Lahan. Gadjah Mada University Press. Yogyakarta

Hutabarat, S., S. Evans. 1984. Pengantar Oceanografi. Universitas Indonesia Press, Jakarta.

Indriyanto. 2006. Ekologi Hutan. PT Bumi Aksara. Jakarta.

Keputusan Menteri Negara Lingkungan Hidup No. 201 tahun 2004 tentang Kriteria Baku dan Pedoman Penentuan Kerusakan Mangrove.
Kustanti A, Yulia RF. 2005. Laporan Pengelolaan Terpadu hutan Mangrove. Kerjasama: Masyarakat, Universitas Lampung, dan Kabupaten Lampung Timur. Universitas Lampung. Bandar Lampung

Nontji, A. 2002. Laut Nusantara. Djambatan, Jakarta.

Purbani. D., 1999. Aplikasi Geografi Fisik Indonesia - Kawasan Wisata Pesisir di Pulau Lombok. Pasca Sarjana Ilmu Geografi UI. Jakarta. Simond, J. O., 1978, Eartscape, New York: McGraw Hill Book Company.

Tuwo, A., 2011. Pengelolaan Ekowisata Pesisir dan Laut: Pendekatan Ekologi, Sosial-Ekonomi, Kelembagaan dan Sarana Wilayah. Brilian Internasional, Surabaya

Undang-Undang Nomor 9 Tahun 1990 Tentang Kepariwisataan Bab I pasal 3.

Undang-Undang Nomor 41/1999 dan UndangUndang No. 19/2004 yang mengatur tentang Kehutanan

Yulianda, F. 2007. Ekowisata Bahari sebagai Alternatif Pemanfaatan Sumberdaya Pesisir Berbasis Konservasi. Disampaikan pada Seminar Sains 21 Februari 2007. Departemen M FPIK. IPB. Bogor. 